UDC 81-2

DOI https://doi.org/10.32447/2663-340X-2021-9.16

\title{
THE REPRESENTATION OF DEFINITENESS/INDEFINITENESS IN THEORY AND PRACTICE
}

\author{
Koval Natalia \\ PhD, Assistant Professor of the Department of Germanic Languages and Translation Studies \\ Drohobych Ivan Franko State Pedagogical University \\ Str. Ivan Franko, 24, Drohobych, Lviv Region, Ukraine
}

Ocheretna Olga

PhD, Assistant Professor of the English Language Department № 2

National university "Odessa Maritime Academy"

Str. Dukovskaya, 5, Odesa, Ukraine

\author{
Koliasa Olena \\ PhD, Assistant Professor of the Department of Germanic Languages and Translation Studies \\ Drohobych Ivan Franko State Pedagogical University \\ Str. Ivan Franko, 24, Drohobych, Lviv Region, Ukraine
}

\begin{abstract}
The article studies how the category of definiteness/ indefiniteness is expressed in English and Ukrainian: in Ukrainian, this category is expressed using different levels of the language; in English, this category is grammatical and expressed using the definite and indefinite articles. A closer look at the problem of the article category in English is taken, described the functions of each article, and examples provided. The aim of the research is to study the category of definiteness/ definiteness in the English and Ukrainian languages, as well as a comparative analysis of the referential indicators of noun phrases. The object of the research is the noun phrases in the English and Ukrainian languages, the referential indicators used with them and their semantics. The main function of the article in English is the function of determination, which introduces the meaning of definiteness/indefiniteness. The relevance and novelty of the work are due to the need to study noun phrases from the point of view of referential semantics and comparative analysis of this category in analytical English and synthetic Ukrainian since the status of this category in Ukrainian is controversial and open. The morphological category of the article in English was examined in detail. The conclusion is that the article does not convey syntactic relations, but performs a determinative function, creates a rheme-thematic division of the text, brings the meaning of definiteness/indefiniteness to a sentence/ text. Various points of view regarding the category of articles in English are considered; the presence of these points of view indicates the complexity of the phenomenon under study and allows asserting that this problem remains relevant. The basic notions of the theory of reference and classification of referential statuses that are currently distinguished in modern linguistics are studied. It is found out that nominal and predicative groups acquire reference; referential noun phrases in English are marked with the grammatical category of articles, in Ukrainian with pronouns that play an important role in defining the meaning of an utterance and defining its referential status.
\end{abstract}

Key words: article, definiteness, determiner, grammar, indefiniteness, reference

Introduction. In the modern linguistic literature, there are many works devoted to the study of the category of definiteness/ indefiniteness and ways of expressing it on the material of different languages. Some scholars question the existence of this category in languages where there is no grammatically expressed category of articles. The research considers the ways of definiteness/ indefiniteness expression in English and Ukrainian and provides its general information.

Theoretical framework. Thus, this research is devoted to the analysis and comparison of the category of definiteness/ indefiniteness in English and Ukrainian languages. The work is written in the scientific direction of referential semantics and is the development of the ideas of N.D. Arutyunova [1], I.M. Kobozeva [2], E.V. Paducheva [3], and others, who formed the scientific basis for this study.

The aim of the research is to study the category of definiteness/ definiteness in the English and Ukrainian languages, as well as a comparative analysis of the referential indicators of noun phrases. 
To achieve this goal, the following tasks were set: to define the category definiteness/ indefiniteness in English and Ukrainian; to analyze the stylistic functioning of references in fiction; to study the ways of usage of references and their expressive functioning in a literary text.

The object of the research is the noun phrases in the English and Ukrainian languages, the referential indicators used with them and their semantics.

Research findings. In any modern language, the meaning of definiteness/ indefiniteness is expressed in different ways. The opposition according to the definiteness/indefiniteness of the referent in many languages is marked grammatically - with the help of a special lexico-grammatical category of words - articles, definite and indefinite. In other languages, where the category of definiteness/ indefiniteness is not grammatical, other categories of the language can serve as actualizers of the corresponding noun phrases.

In many Germanic languages, there is a special grammatical category of articles, with the help of which the meaning of definiteness/ indefiniteness is expressed.

The question of the existence of the category of definiteness/ indefiniteness in the Ukrainian language has been controversial in linguistics for many years. In Ukrainian, the meaning of definiteness/ indefiniteness is expressed using different levels of the language:

- the lexical - is a combination of a noun with an indefinite or demonstrative pronoun: this, that, someone, etc. It should be noted that this method is also typical for the English language;

- syntactic method - position in the sentence. The alternation of a theme (already known) and rheme (new information) creates an actual division of the text. Since in English there is a fixed order of words in a sentence, this way of expressing the category of definiteness/ indefiniteness is not typical. Although there is also the notion of inversion, which emphasizes that the subject is rheme;

- a method close to affixation: the attachment of a particle is something that expresses a certain meaning;

- grammatical categories of a noun - opposition of accusative and genitive cases;

- numeral one, corresponding in function to the indefinite article $a / a n$;

- verb categories: tense, voice, mood;

From the Old Church Slavonic language in the modern Ukrainian language, a way of expressing definiteness/indefiniteness with the help of full and short forms of adjectives has been preserved. Full forms of adjectives have functions of the article and express certainty, in contrast to short ones, in which this function is weakened.

To denote determination in modern linguistics, the terms actualization, quantification, and reference are used. In English, the indicator of determination is the category of articles. The article defines the uniqueness, exclusivity of an object in the described situation, or refers it to the class of similar phenomena or objects.

In the process of communication, the use of articles allows one to perceive the meaning of the statement more accurately and unambiguously, which contributes to the achievement of mutual understanding between the speaker and the listener. The article does not convey the syntactic relations of the name in the sentence, but performs the function of determination, introduces the meaning of definiteness/ indefiniteness in a text: the introduction of a new one or an indication of anaphoricity (theme-rhematic organization of the sentence), the meaning of the generalized class, the meaning of the emotionality of a statement and other meanings.

At the moment, there are several views on the morphological category of the article. Not all scholars regard the article as an independent part of speech. O. Espersen refers to this category to indefinite and demonstrative pronouns, L.S. Barkhudarov considers the article to be a special word-determinant of pronominal origin, A. Vinogradov puts the article in the category of functional words and highlights the main function of the articles - indicating the type of reference.

There is also no consensus on the number of articles in modern English. Some scholars think that there are only two articles in English, while others recognize the status of the "zero article." Existing points of view indicate the complexity of the phenomenon under study, therefore the article problem remains relevant today.

In the Ukrainian language, the category of definiteness/ indefiniteness is not grammatical; pronouns can serve as actualizers of the corresponding referential statuses. The translators are faced with the task of finding words in Ukrainian that are semantically equivalent to these articles.

A reference (Latin refero - attaching, comparing) is the relation of a word and an object/ situation, which are indicated by this word. The phenomenon of reference is the correlation of an assumption with a phenomenon of reality.

E.V. Paducheva gives the following definition to this phenomenon: "Reference is a correlation, generally speaking, with individual and each time new objects and situations" [3]. 
According to N.D. Arutyunova, reference is presented as "A way to hook a statement to the world." Reference as an action (correlation) is carried out by the speaker, is a separate component in a speech act. Reference as a result (correlation) is a relation into which linguistic expressions enter in the context of a speech act [1]. Thus, the theory of reference raises the question of how a word relates to the desired object.

Reference theory studies how a word is related to a denotation (designated object). There are two categories of linguistic expressions that acquire referential status in the context of an utterance. This is, firstly, a noun phrase, which can be expressed in one or more words, and secondly, a predicate group.

In the theory of reference, a noun phrase is a combination of two elements: a common name and its actualizer. A common name is a vocabulary unit (for example, a house, a river), or a syntactically complex formation (for example, a beautiful house), possibly even containing some actualized noun phrases (for example, a house that belonged to that man). A common name has an extension the set of all possible referents. The extension of a common name is an abstract set that exists only under the abstraction of actual infinity; for example, the extension of the word house is the set of all houses that were, are and will be.

Actualizers (according to $\mathrm{Ch}$. Balli) are those words and, in general, components of a sentence that turn a common name into an actualized noun phrase. S. Bally and his followers consider the actualizer as a means of referring, and the actualized that participates in the reference [1].

For example, from a common name a young man; you can get noun phrases for this young man; all young people; some young man who is meant to be related to an object. The number of actualizers includes such words (and phrases) as this, that, the same, each, each of, any of, such, any, all, all except one, whatever, none, some, this or that, whatever, one, at least one, more than one, two, both, at least two, more than two, all three, several, many, many of, the other, etc.

With all the variety of specific correlations of noun phrases with extra-linguistic objects, the number of different types of correlation is relatively small. Researchers distinguish different types of reference based on the intersection of the following three main meanings the meaning of the existence/non-existence of an object; the value of the known / unknown subject/ object; the criterion of being known/ unknown that plays an important role in organizing the utterance, since, when communicating certain information to the interlocutor, the speaker is guided by the degree of his awareness of the subject of speech to avoid misunderstanding. In addition, the importance of this criterion is confirmed by the fact that the realization of the meaning of known/ unknown occurs most often in the process of communication and recklessly used actualizers can lead to a communication failure.

The actualizer as part of the noun phrase can be zero, i.e. actualization can be achieved by simply including a word in a sentence. The denotational status of a noun phrase is determined in this case by the context and linearly intonational structure of the sentence.

Some noun phrases cannot be divided linearly into an actualizer and a common name. Semantically, such noun phrases represent either a pure actualizer or a combination of an actualizer with a semantic component of an abstract type.

The denotative status of a noun phrase is determinedbythemeaningofitsactualizer.However, not always the entire semantic contribution that the actualizer makes to the sense of the sentence is included in the denotative characteristic of the noun phrase. The sentences You can take some book and You can take one book are different in meaning: the use of a pronoun is associated with the idea of the qualitative heterogeneity of the class of objects from which the choice occurs, and the numeral one does not carry this idea, cf. the fact that the sentence You can take one apple is normal, but You can take an apple sounds strange [15].

Denotational statuses are semantic labels. They characterize the sentence and are independent of the speech act. Although status characterizes the type of reference, in natural languages this aspect of meaning is closely intertwined with many pragmatic meanings - first of all with the opposition "certainty/ uncertainty" for speakers [13], as in articular languages the opposition between referential/ non-referential and definite/ indefinite is regularly expressed by the same means.

Opposition according to the definiteness/ indefiniteness of the referent in many languages is marked grammatically - with the help of a special lexico-grammatical category of words - articles, definite and indefinite. In other languages, where the category of definiteness/ indefiniteness is not grammatical, pronouns can serve as actualizers of the corresponding noun phrases. In Ukrainian, demonstrative pronouns are used for a definite reference and indefinite pronouns for an indefinite one. But in both types of languages, the presence in the composition of a linguistic expression of a special actualizer of definiteness/ indefiniteness is not always a necessary condition for the 
implementation of the corresponding type of reference.

Consider the following examples: I have already read the book you gave me.

I have read this book.

The uniqueness of the object in these sentences is included in the meaning of the actualizer. For example, in sentence 2) this book = "the book at which the speaker's pointing gesture is directed"; therefore, the meaning of sentence 2) includes the presumption "There is only one book to which the speaker points with a gesture." The nominative group is the book that you gave me sentences 1) corresponds to the presumption "There is only one book that you gave me."

Non-referential statuses.

Utterance and its correlation with reality in nonreferential noun phrases distinguish the following denotative statuses: 1) existential; 2) universal; 3) attributive; 4) generic.

Existential noun groups are used in a situation when it comes to an object (in particular, a set of objects) that belongs to the class of objects of the same kind and is not individualized, i.e. something that is unknown to the speaker, but in principle cannot be presented or indicated, since he is "not selected" [13] from this class.

Generally, existential noun phrases allow speaking about objects with certain properties, without referring to specific objects. Let's look at some examples:

General existential status is the status of the subject in the so-called private judgments of traditional logic, i.e. in judgments about a part of an abstract (universal) set.

"And I'm willing to agree with his housekeeper that although some people think he's proud, I didn't feel it at all." (1, J. Austin "Pride and Prejudice")

Here some people indicate a general judgment inherent in the majority, it does not mean any specific group of people.

Noun phrases have a universal status, the referent of which is the entire set of entities, denoted by the corresponding nominal expression, i.e. the extension of this expression. The actualizers of this status are attributive pronouns with the meaning of universality: everything, everyone, everyone. Of course, each of these pronouns has its characteristics. So, unlike everything, each, in addition to universality, is labelled based on distribution.

A noun phrase can be interpreted as universal only if it is based on a common name with an open extension.

"Low is any method women use to attract men." (1, J. Austin "Pride and Prejudice")
In this example of noun phrases, any method presupposes a variety of existing methods, the extension of the word is not limited by anything, which means that these noun phrases can be interpreted as universal.

Attributive status is illustrated by the phrase "Smith's killer is crazy" in the sense that the speaker means the presumption of the existence and uniqueness of the killer, but does not imply any specific person. This statement can be made in a situation where the killer is generally unknown to the speaker, and he bases his judgment only on the brutal nature of the murder. The attributive use of a description always requires a specific context.

Note also that in addition to the specific context described above, there is another context that allows attributive descriptions is the context of a generalizing statement.

"I think I'm not mistaken if I say that there may be someone among us who is unlikely to enjoy the ball." (1, J. Austin "Pride and Prejudice")

In this example, the attributive noun phrase someone unlikely to enjoy the ball is generalized, the author does not specify the participant in the situation.

In the generic use of a noun phrase, the referent is the non-individualized representative of the set of entities that make up the extension of the corresponding nominal expression.

Generic use is not referential, since it does not oblige the speaker to acknowledge the existence of an individualized object in the universe of speech: the genus of objects is discussed using the example of one representative. In the phrase Someday a person will visit Mars, the generic interpretation of the word person is preferable to the existential one since it is clear that we are talking not just about a person, but about a representative of the human race. Generic use of a noun phrase by a person can be observed in the following examples:

"For it is said that a person is never satisfied with what he has achieved: give him what he wants and he will ask for something else. Yes! It is said - to be little man, while this is one of his most remarkable talents, it is a talent that lifts man above animals, content with what they have." (2, John Steinbeck "Pearl")

Conclusion. The theory of reference studies the systemic relations of linguistic means in different languages and their expression in a literary text raises the question of how a word relates to an object.

Referential statuses are divided into two groups: referential and non-referential. Reference statuses include certain, poorly defined, and undefined noun phrases. Non-referential statuses include existential, universal, attributive and generic. 
Definite noun phrases imply being known for the speaker and the listener, and indefinite imply uncertainty for both the speaker and the listener.

Existential noun phrases imply a non-individualized object belonging to the same class of objects.

Noun phrases can be considered universal, provided that it is based on a common name with an open extension.

Attributive noun phrases represent a plausible inference from incomplete information.

Generic noun phrases are used in a situation where the genus of objects is described using the example of one representative.
In modern linguistics, two categories of linguistic expressions are distinguished, which acquire a reference: the noun phrase and the predicate group. A nominative group consists of a common name and an actualizer. A predicate group is a pure common name in non-articulate languages; such a group does not include an actualizer.

In some cases, the actualizers included in the noun phrase play a significant role in determining the meaning and, therefore, the referential status of the given noun phrase.

\section{BIBLIOGRAPHY}

1. Арутюнова Н.Д. Лингвистические проблемы референции. НЗЛ. М.: Прогресс, 1982.

2. Кобозева И.М. Лингвистическая семантика, 2002.

3. Падучева Е.В. Высказывание и его соотнесённость с действительностью. М.: Наука, 1985.

4. Abbott B. Definiteness and indefiniteness. In Horn L R \& Ward G (eds.) The handbook of pragmatics. Oxford: Blackwell, 2004. P. 122-149.

5. Ariel M. Accessing noun phrase antecedents. London: Routledge, 1990.

6. Ariel M. Accessibility theory: an overview. In Sanders T, Schliperoord J \& Spooren W (eds.) Text representation. Amsterdam and Philadelphia: John Benjamins,2001. P. 29-87.

7. Birner B. J. \& Ward, G. Information status and noncanonical word order in English. Amsterdam and Philadelphia: John Benjamins, 1998.

8. Definite and Indefinite Encyclopedia of Language \& Linguistics, 2006, vol. 3. P. 392-399.

9. Du Bois J. W. Beyond definiteness: the trace of identity in discourse. In Chafe W. L. (ed.) The pear stories: cognitive, cultural, and linguistic aspects of narrative production. Norwood, NJ: Ablex, 1980. P. 203-274.

10. Haspelmath M. Indefinite pronouns. Oxford: Oxford University Press, 1997.

11. Hawkins J. A. Definiteness and indefiniteness. Atlantic Highlands, NJ: Humanities Press, 1978.

12. Hawkins J. A. On (in)definite articles: implicatures and (un)grammaticality prediction. Journal of Linguistics, 27 , 1991. P. 405-442.

13. Heim I. The semantics of definite and indefinite noun phrases. Ph.D. diss., University of Massachusetts, 1982.

14. Heim I. File change semantics and the familiarity theory of definiteness. In Bauerle R, Schwarze C \& von Stechow A (eds.) Meaning, use and the interpretation of language. Berlin: Walter de Gruyter, 1983. P. 164-189.

15. Lewis D. Scorekeeping in a language game. Journal of Philosophical Logic 8, 1979. P. 339-359.

16. Roberts C. Uniqueness in definite noun phrases. Linguistics and Philosophy, 26, 2003. P. 287-350.

17. Woisetschlaeger E. On the question of definiteness in “an old man's book." Linguistic Inquiry, 14, 1983. P. 137-154.

\section{ILLUSTRATIVE MATERIAL}

1. Austen, J. (2003). Pride and Prejudice (V. Jones, Ed.). Penguin Classics.

2. Steinbeck, J. (2000). The Pearl. Penguin Classics.

\section{REFERENCES}

1. Arutunova, N.D. (1982). Lingvisticheskie problemy referencii. [Linguistic problems of reference]. NZL. M.: Progres, 1982. [in Russian]

2. Kobozeva, I.M. (2002). Lingvisticheskaya semantica [Linguistic semantics]. M. [in Russian]

3. Paducheva, E.V. (1985). Vyskazyvanie i ego sootnesennost s deistvitelnostyu. [Utterances and their reference with reality]. M.: Nauka. [in Russian]

4. Abbott, B. (2004). Definiteness and indefiniteness. In Horn L R \& Ward G (eds.) The handbook of pragmatics. Oxford: Blackwell, 122-149. [in English]

5. Ariel, M. (1990). Accessing noun phrase antecedents. London: Routledge. [in English]

6. Ariel, M. (2001). Accessibility theory: an overview. In Sanders T, Schliperoord J \& Spooren W (eds.) Text representation. Amsterdam and Philadelphia: John Benjamins, 29-87. [in English]

7. Birner, B. J. \& Ward, G. (1998). Information status and noncanonical word order in English. Amsterdam and Philadelphia: John Benjamins. [in English] 
8. Definite and Indefinite Encyclopedia of Language \& Linguistics (2006), vol. 3, 392-399. [in English]

9. Du Bois, J. W. (1980). Beyond definiteness: the trace of identity in discourse. In Chafe W. L. (ed.) The pear stories: cognitive, cultural, and linguistic aspects of narrative production. Norwood, NJ: Ablex, 203-274. [in English]

10. Haspelmath, M. (1997). Indefinite pronouns. Oxford: Oxford University Press. [in English]

11. Hawkins, J. A. (1978). Definiteness and indefiniteness. Atlantic Highlands, NJ: Humanities Press. [in English]

12. Hawkins, J. A. (1991). On (in)definite articles: implicatures and (un)grammaticality prediction. Journal of Linguistics, 27, 405-442. [in English]

13. Heim, I. (1982). The semantics of definite and indefinite noun phrases. Ph.D. diss., University of Massachusetts. [in English]

14. Heim, I. (1983). File change semantics and the familiarity theory of definiteness. In Bauerle R, Schwarze C \& von Stechow A (eds.) Meaning, use and the interpretation of language. Berlin: Walter de Gruyter, 164-189. [in English]

15. Lewis, D. (1979). Scorekeeping in a language game. Journal of Philosophical Logic. 8, 339-359. [in English]

16. Roberts, C. (2003). Uniqueness in definite noun phrases. Linguistics and Philosophy, 26, 287-350. [in English]

17. Woisetschlaeger, E. (1983). On the question of definiteness in "an old man's book." Linguistic Inquiry, 14, 137-154. [in English]

\title{
ПРЕДСТАВЛЕННЯ КАТЕГОРІЇ ОЗНАЧЕНОСТІ/НЕОЗНАЧЕНОСТІ В ТЕОРІЇ ТА ПРАКТИЦІ
}

\author{
Коваль Наталія \\ $P h D$, \\ дочент кафедри німецьких мов та перекладознавства \\ Дрогобиџького державного педагогічного університету імені Івана Франка \\ вул. Івана Франка, 24, м. Дрогобич, Львівська область, Україна \\ Очеретна Ольга \\ $P h D$, \\ дочент кафедри англійської мови № 2 \\ Національного університету "Одеська морська академія" \\ вул. Дуковська, 5, Одеса, Україна \\ Коляса Олена \\ $P h D$, \\ доиент кафедри германських мов та перекладознавства \\ Дрогобииького державного педагогічного університету імені Івана Франка \\ вул. Івана Франка, 24, м. Дрогобич, Львівська область, Украӥна
}

\begin{abstract}
Стаття має на меті дослідити як категорія означеності/ неозначеності виражається в англійській та украӥнській мовах. В ураїнській мові ия категорія виражається з використанням різних рівнів мови; англійською мовою ия категорія є граматичною $і$ виражається за допомогою означеного та неозначеного артиклів. Розглядається проблема вираження категорії означеності/ неозначеності за допомогою артикля а англійській мові, описуються функиї кожного артикля та наводяться приклади. Метою дослідження є вивчення категорії означеності/ неозначеності в англійській та украӥнській мовах, а також порівняльний аналіз референтних показників іменникових виразів. Об'єктом дослідження є категорія означеності/ неозначеності в англійській та украӥнській мовах, референтні індикатори та їх семантика. Основною функиією артикля в англійській мові є функиія означення, визначення, яка вводить значення означеності/ неозначеності. Актуальність та новизна роботи зумовлені необхідністю вивчення іменникових фраз з точки зору референтної семантики та порівняльного аналізу иієї категорії в аналітичній англійській та синтетичній украӥнській мовах, оскільки статус иієї категорії в українській мові є суперечливим та відкритим. Детально розглянуто морфологічну категорію артикля в англійській мові. Висновок полягає в тому, щзо артикль англійської мови не передає синтаксичних відношень, а виконує визначальну функцію, створює реме-тематичний поділ тексту, вносить значення означеності/ неозначеності в речення / текст. Розглядаються різні точки зору щодо категорії артикля в англійській мові; наявність ичих точок зору вказує на складність досліджуваного явища і дозволяє стверджувати, щุo ияя проблема залишається актуальною. Вивчаються основні поняття теорії класифікації референційних
\end{abstract}


статусів, які в даний час виділяються в сучасній лінгвістиці. 3'ясовано, щзо іменні та предикативні групи набувають посилання; референтні іменні фрази англійської мови позначені граматичною категорією артикля, а в українській мові займенники, які відіграють важливу роль у визначенні значення висловлювання та визначенні його адресного статусу.

Ключові слова: грамматика, іменник, категорія, мовні рівні, неозначеність, означеність, референт 